\title{
WATER USE EFFICIENCY AND PEPPER YIELD UNDER DIFFERENT IRRIGATION AND FERTILIZATION REGIME\#
}

\author{
Vjekoslav Tanaskovik ${ }^{1 *}$, Ordan Cukaliev ${ }^{1}$, Davor Romić ${ }^{2}$, Gabrijel Ondrasek ${ }^{2}$, Radovan Savić ${ }^{3}$, \\ Mile Markoski ${ }^{1}$, Stojanche Nechkovski ${ }^{1}$
}

${ }^{1}$ Faculty of Agricultural Sciences and Food, University St. Cyril and Methodius, Skopje, Republic of Macedonia

${ }^{2}$ Faculty of Agriculture, University of Zagreb, Republic of Croatia

${ }^{3}$ Faculty of Agriculture, University of Novi Sad, Serbia

e-mail: vtanaskovic@fznh.ukim.edu.mk

\begin{abstract}
The primary objective of this study was to determine water use efficiency (WUE) and pepper yield under different irrigation and fertilization regimes. For this purpose, a three-year field experiment was conducted with pepper, grown in a plastic house in the Skopje region. Four experimental treatments were applied in this study. Three of the treatments were drip fertigated $\left(\mathrm{DF}_{1}, \mathrm{DF}_{2}, \mathrm{DF}_{3}\right)$, while the last one was furrow irrigated with conventional application of fertilizer $\left(\varnothing_{\mathrm{B}}\right)$. The results obtained clearly showed that treatments $\mathrm{DF}_{1}, \mathrm{DF}_{2}$, and $\mathrm{DF}_{3}$ resulted in significantly higher marketable and dry pepper yield in comparison to treatment $\varnothing_{\mathrm{B}}$. Also, drip fertigation frequency at four and two days $\left(\mathrm{DF}_{2}\right.$ and $\left.\mathrm{DF}_{1}\right)$ resulted in $9.6 \%$ to $13.6 \%$ higher marketable and $17.6 \%$ to $20.1 \%$ dry pepper yield when compared with drip fertigation scheduled by tensiometers $\left(\mathrm{DF}_{3}\right)$. Also, our results indicate that drip fertigation is an effective practice in achieving significantly higher WUE. Namely, WUE was $2.50,2.47,1.99$ and $1.54 \mathrm{~kg} / \mathrm{m}^{3}$ for the treatments $\mathrm{DF}_{1}$, $\mathrm{DF}_{2}, \mathrm{DF}^{3}$ and $\emptyset_{\mathrm{B}}$, respectively.
\end{abstract}

Key words: furrow irrigation; conventional fertilization; drip fertigation; yield; water use efficiency

\section{INTRODUCTION}

Water scarcity and drought are the major factors constraining agricultural crop production in arid and semi-arid zones of the world. Innovations for saving water in irrigated agriculture and thereby improving water use efficiency are of paramount importance in water-scarce regions [1].

Worsened water availability conditions caused by the recent processes of climate warming evoke the attention of the scientists to the efficiency of the water use by crops [2]. A useful tool for successful yield and water management is the yieldwater relationship [2,3]. Development of water and fertilizer management technology that improve water use efficiency is the key to guaranteeing sustainable cultivation of facilities vegetable [4]. However, efficient use of water by irrigation is becoming in- creasingly important, and alternative water application method such as the dripping one may contribute substantially to the best use of water for agriculture and to improving the irrigation efficiency [5].

Pepper is one of the most important vegetable crops produced under irrigated agriculture [6]. According to Dorji et al. [7], pepper production is confined to the warm and semi-arid countries where water is often a limiting factor for production, necessitating the need to optimize water management. Furthermore, Tanaskovik [8] reported that pepper is among the most sensitive horticultural plants to drought stress. Such sensitivity has been noticed in several researches that studied the fresh and dry matter yield reduction affected by water stress [9-12]. Generally, the low pepper yield may be associated with water stress or inadequate soil nutrient $[13,14]$, which is a result of inadequate 
water and soil nutrients procurement affected by irrigation and fertilization regime [15-17]. However, water shortage can be more detrimental to pepper than nutrient deficiency [18].

The pepper water requirements during the vegetation period are quite big compared to other crops, which is a result of the poorly developed root system [19] and large transpiring leaf surface [20, 21]. Water deficit during the period between flowering and fruit development reduces the final productivity of pepper $[22,23]$. Therefore, in order to obtain high yields, pepper needs to be provided with adequate quantities of water throughout the vegetation period. In this relation, many authors have elaborated the topic as to how much attention should be paid to irrigation practice of pepper crop [9, 13, 16, 24-31].

Generally, the pepper producers in the Republic of Macedonia have used drip irrigation systems to increase the yield in recent years, but more research is still needed, related to the proper use of water and fertilizers to maximize pepper yield [17]. Also, there are limited results for water use efficiency under different irrigation and fertilization regimes. Therefore, the main objectives of this study were to compare irrigation and fertilization regimes in order to improve water use efficiency, with an aim not only to improve the pepper yield but also to increase the farmer's benefits and tenvironmental protection.

\section{MATERIAL AND METHODS}

The field experiment was conducted with pepper crop (Capsicum annum L. var. Bela dolga) pruned at two main shoots ("V" system) and grown in experimental plastic house nearby the Faculty of Agricultural Sciences and Food in Skopje, Republic of Macedonia ( $42^{\circ} 00^{\prime} \mathrm{N}, 21^{\circ} 27^{\prime} \mathrm{E}$ ), during the period of May to October in 2005, 2006 and 2007. The soil type of experimental field is Fluvisol [32] with average field capacity of the $0-60 \mathrm{~cm}$ soil layer $30.31 \%$, at a permanent wilting point $-12.61 \%$, and soil bulk density $-1.52 \mathrm{~g} / \mathrm{cm}^{3}$. The average soil $\mathrm{pH}$ at 0 to $60 \mathrm{~cm}$ depth was 7.30 , while soil electrical conductivity ECe was $2.31 \mathrm{dS} / \mathrm{m}$. The soil 0-60 $\mathrm{cm}$ layers contained respectively $2.80 \mathrm{mg} / 100 \mathrm{~g}$ available forms of $\mathrm{N}, 13.2 \mathrm{mg} / 100 \mathrm{~g}$ available $\mathrm{P}_{2} \mathrm{O}_{5}$ and $22.5 \mathrm{mg} / 100 \mathrm{~g}$ available $\mathrm{K}_{2} \mathrm{O}$.

Table 1. Chemical and physical characteristics of the $0-60 \mathrm{~cm}$ soil layer

\begin{tabular}{ll}
\hline Chemical characteristics & \\
\hline Reaction (pH in water) & 8.04 \\
Electrical conductivity (ECe dS/m) & 2.31 \\
$\mathrm{CaCO}_{3} \%$ & 3.54 \\
Organic matter \% & 0.77 \\
Available $\mathrm{N}$ mg/100 g soil & 2.80 \\
Available $\mathrm{P}_{2} \mathrm{O}_{5} \mathrm{mg} / 100 \mathrm{~g}$ soil & 13.2 \\
Available $\mathrm{K}_{2} \mathrm{O} \mathrm{mg} / 100 \mathrm{~g}$ soil & 22.5 \\
\hline Particle size of the soil layer & 62.2 \\
\hline Total sand in \% & 13.0 \\
Silt in \% & 24.8 \\
Clay in \% & \\
\hline Water physical properties & 34.37 \\
\hline Permanent wilting point (soil moisture retention at 15 bars) in volume $\%$ & 1.52 \\
\hline Field capacity (soil moisture retention at 0,33 bars) in volume \% \\
Bulk density in g/cm ${ }^{3}$ & \\
\hline
\end{tabular}

According to the literature data for the region [19], pepper planted in our conditions and yields up to $60 \mathrm{t} / \mathrm{ha}$ need the following amount of nutrients: $485 \mathrm{~kg} / \mathrm{ha} \mathrm{N}, 110 \mathrm{~kg} / \mathrm{ha} \mathrm{P}$ and $485 \mathrm{~kg} / \mathrm{ha} \mathrm{K}$. The application of the fertilizer for the treatments was done in two portions. The first application of fertilizers was applied before transplanting of pepper, while the remaining amount of fertilizers was applied through the fertigation system for drip fertigation treatments (Table 2) and conventional fertilization for the control treatment (in two applications, one application at the flowering and second application at fruit formation). Namely, all investigated treatments have received the same amount of fertilizers, but with different methods and frequency of application. 
Table 2. Type and amount of fertilizers used in drip fertigation treatments in $\mathrm{kg} / \mathrm{ha}$

\begin{tabular}{ccl}
\hline Type of fertilizers & Amount of applied fertilizer & \multicolumn{1}{c}{ Period of application } \\
\hline $15: 15: 15$ & $318 \mathrm{~kg} \mathrm{ha}^{-1}$ & before transplanting \\
$0: 52: 34$ & $375 \mathrm{~kg} \mathrm{ha}^{-1}$ & drip fertigation during the vegetation \\
$0: 0: 51+18 \mathrm{~S}$ & $802 \mathrm{~kg} \mathrm{ha}^{-1}$ & drip fertigation during the vegetation \\
$46: 0: 0$ & $952 \mathrm{~kg} \mathrm{ha}^{-1}$ & drip fertigation during the vegetation \\
\hline
\end{tabular}

*Remark: the same amounts and quantity of fertilizers were used for furrow irrigation treatment

The drip irrigation system was designed according to the objectives of the study. Polyethylene pipe with $32 \mathrm{~mm}$ diameter was used as the main line to supply irrigation water, while $20 \mathrm{~mm}$ for submain lines. Lateral lines were equipped with integrated compensating drippers with a discharge of 4 $1 / \mathrm{h}$ each crop row. The spacing between the lateral drip pipes was $0.75 \mathrm{~m}$, while the spacing between emitters was $0.33 \mathrm{~m}$. The fertigation equipment used for drip fertigation treatments was Dosatron 16, with a plastic barrel as a reservoir for concentrated fertilizer. Electrical Conductivity of the irrigation nutrient solution throughout the cultivation season was between $0.5-0.7 \mathrm{dS} / \mathrm{m}$. The source of water was of high quality (municipal water supply system for the city of Skopje). The water flow meter was installed for measuring the irrigation application rate.

The first irrigation application rate for all treatments in all three experimental years was based on the soil moisture deficit that would be needed to bring the $0-60 \mathrm{~cm}$ soil layer to field capacity. The irrigation program in all three years started immediately after the first irrigation application rate (around 20 $0^{\text {th }}$ May) and according to the experimental treatments designed for this study presented below. The last irrigation application rate was realized seven days before the last harvest (around $15^{\text {th }}$ October). The irrigation scheme of the experiment (treatment $\mathrm{DF}_{1}, \mathrm{DF}_{2}$, and $\varnothing_{\mathrm{B}}$ ) was scheduled according to the long-term average (LTA) daily evapotranspiration of pepper in the Skopje region (Figure 1). LTA crop evapotranspiration was calculated by using FAO software CROPWAT for open field and by using crop coefficient $\left(\mathrm{K}_{\mathrm{c}}\right)$ and stage length adjusted for the local condition.

The irrigation scheme used in the experiment was designed according to a randomized block design for experimental purposes with four treatments, each treatment replicated three times. The experimental treatments were set up according to the daily evapotranspiration rate. The following experimental treatments were applied in this study: Drip fertigation according to daily evapotranspiration rate with application of water and fertilizer in every two days $\left(\mathrm{DF}_{1}\right)$; Drip fertigation according to daily evapotranspiration rate with application of water and fertilizer in every four days $\left(\mathrm{DF}_{2}\right)$; Drip fertigation scheduled with ten- siometers $\left(\mathrm{DF}_{3}\right)$ with recommendations undertaken by Tekinel and Kanber [26]; Furrow irrigation according to daily evapotranspiration with application of water in every seven days and conventional fertilization $\left(\emptyset_{\mathrm{B}}\right)$. The daily evapotranspiration rate of $\mathrm{DF}_{1}$ and $\mathrm{DF}_{2}$ was decreased by $20 \%$ (coverage coefficient) as a result of applied irrigation technique and regime, similarly to Xie et al. [33].

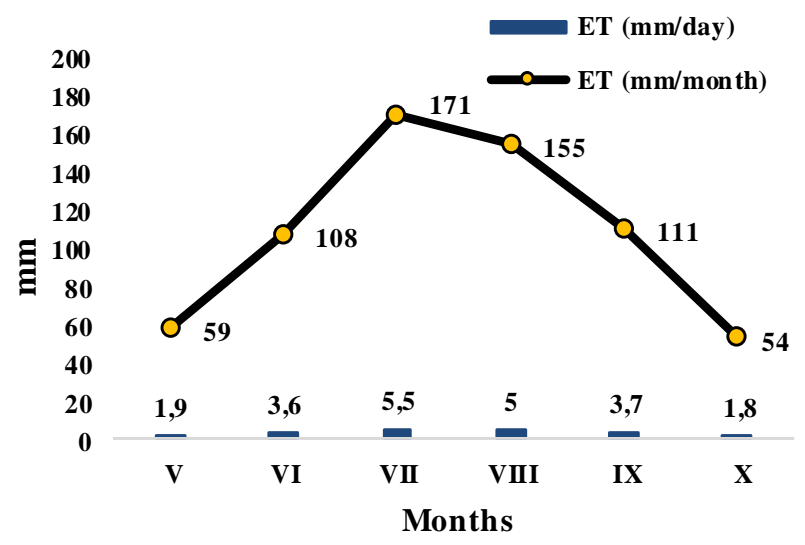

Figure 1. Long-term average daily and monthly evapotranspiration $(\mathrm{mm})$ of pepper

in Skopje region calculated by FAO software CROPWAT

Each plot (with a single replication) was designed with five crop rows and five plants in each row. The size of each plot (replication) was $6.6 \mathrm{~m}^{2}$ ( 25 plants in $0.75 \mathrm{~m}$ of row spacing and with $0.35 \mathrm{~m}$ plant spacing in the row). The middle row was assumed for experimental purposes. The experimental plants were three in the middle of the experimental row and these plants were used for sampling and determination of WUE. The picking of fruits from the representative plants was carried out in the stage of technological maturity, part of the leaves, most often the older ones, were picked during the vegetation, the other part of the leaves and the entire stem were collected at the end of the vegetation. The procedure for laboratory preparation of the material was carried out according to the recommendations of IAEA [34]. The results for WUE were obtained as a ratio of the total biomass of dry matter and the seasonal water use by crop (evapotranspiration). 
The data collected were subjected to analyses of variance using R 3.1.3 statistical software. LSD test at $\mathrm{P} \leq 0.05$ was used to group the means per treatment when the F-test was significant.

\section{RESULTS AND DISCUSSIONS}

\section{The meteorological conditions during the research}

The optimal air temperature for growing pepper in a controlled environment is $20-30{ }^{\circ} \mathrm{C}$ during the day time and $18-20^{\circ} \mathrm{C}$ during the night $[35,36]$. Bosland and Votava [22], reported that best pepper yields can be obtained when the air temperature during day time is $18-32{ }^{\circ} \mathrm{C}$, especially during the stage of fruit formation. According to Daşgan and Abak [37], maximum daytime temperatures inside the greenhouse depend on the outside air temperatures and vary from $20{ }^{\circ} \mathrm{C}$ to $34{ }^{\circ} \mathrm{C}$. In our investigation, the average seasonal temperature in the experimental plastic house during 2005, 2006 and 2007 was $22.83^{\circ} \mathrm{C}$, $22.95{ }^{\circ} \mathrm{C}$ and $24.10^{\circ} \mathrm{C}$ respectively (Figure 2 ).

For the normal growth of pepper and for high and quality yields, the optimal relative air humidity should range from 60 to $70 \%$. Gvozdenović et al. [38], reported that lower relative air humidity followed by high air temperature can affect flower and fruit falling. With the exception of October, the average relative air humidity during all three years of investigation was close to the recommended values for pepper production in the protected environment [39].

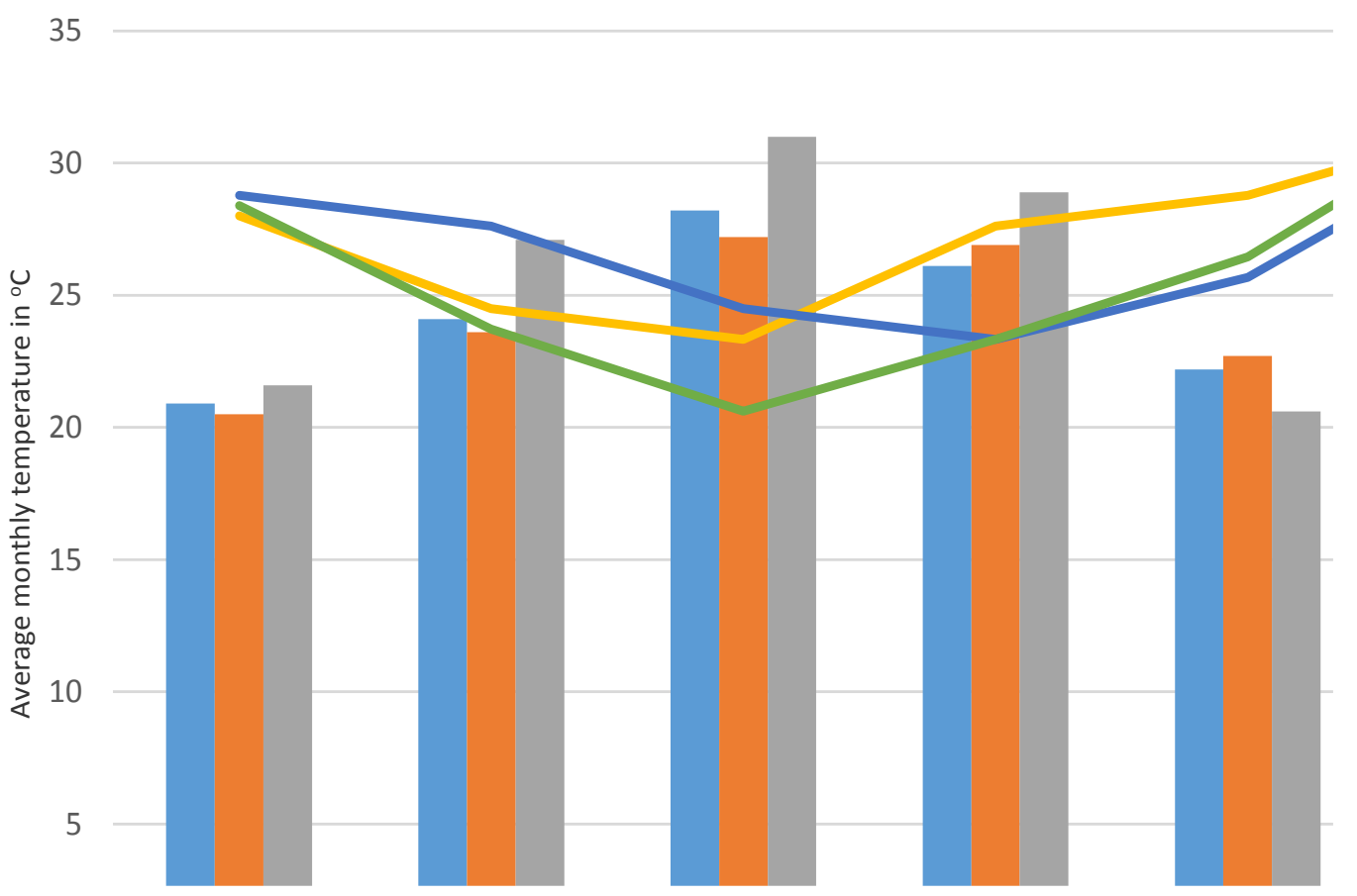

Figure 2. Monthly air temperature $\left({ }^{\circ} \mathrm{C}\right)$ and monthly relative air humidity $(\%)$ in the experimental plastic house (by our measurements)

As was mentioned above, the field experiment was conducted in a controlled environment (plastic house), where precipitation does not have any influence on the crop water supply.

\section{Potential evapotranspiration of pepper under different irrigation and fertigation regime}

Potential evapotranspiration or crop water use (ETP) was determined monthly and seasonally by soil water balance method by using direct measurements over the soil layer $0-100 \mathrm{~cm}$ [40-42] and under permanent content of soil moisture and nutrients, as well as permanent agro-technical measures.

$$
E_{\text {month }}=W_{1}+I-W_{2}
$$

ETP $_{\text {month }}$ in equation 1 presents the potential evapotranspiration $\left(\mathrm{m}^{3} / \mathrm{ha}\right)$ total for each month, $\mathrm{W}_{1}$ is active soil moisture content at the beginning of each month, I is irrigation water $(\mathrm{mm})$ during the month and $\mathrm{W}_{2}$ is active soil moisture content at the end of each month. As was mentioned above, our investigation was realized in an experimental plastic house, where precipitations $(\mathrm{P})$ haven't influence on 
the soil water income. Also, as a result of the controlled irrigation practice of drip and furrow irrigation treatments applied in the study, there were no excess irrigation applications or runoff during the irrigation seasons. Therefore, surface runoff (RO) and deep percolation (DP) were assumed to be zero. Also, the subsurface water and water transported upward by a capillary rise (CR) haven't influence on water income in the root zone, and they were excluded from this estimation. The sum of monthly evapotranspiration present seasonally potential evapotranspiration or ETP $=\mathrm{ETP}_{\text {month } 1}+\mathrm{ETP}_{\text {month } 2}$ $+\ldots .+$ ETP $_{\text {month } x}$ (where ETP month 1, ETP month 2, ETP month $x$, present each individual month included in the investigation). The average results for the monthly and seasonal ETP totals are presented in Table 3.

The seasonal water use (ETP) varied from 4887.9 to $5881.4 \mathrm{~m}^{3} / \mathrm{ha}$ in the different treatments. The highest water use was observed in $\emptyset_{\mathrm{B}}$ treatment with $5881.4 \mathrm{~m}^{3} / \mathrm{ha}$, and the lowest was measured in $\mathrm{DF}_{2}$ and $\mathrm{DF}_{1}$, with 4840.1 and $4887.9 \mathrm{~m}^{3} / \mathrm{ha} . \mathrm{DF}_{3}$ resulted in $5107.3 \mathrm{~m}^{3} / \mathrm{ha}$ seasonally water use. The result for the average seasonal ETP total in our investigation was lower than that recommended by Doorenbos and Kassam [24], from 600 to $900 \mathrm{~mm}$, which is connected with the proper and controlled irrigation and fertilization regime during all three years of investigation. On the other hand, the results for average the seasonal ETP in our investigation were similar to those observed in our previous investigations [17], and vary from 492 to $592 \mathrm{~mm}$. Orgaz et al. [43], reported lower ET in three stems pruned pepper than ours, which was likely enough of different cultivation period and pruning system compared to our investigation.

The results for the average monthly and seasonal ETP in our investigation indicated small differences between the treatments $\mathrm{DF}_{1}$ and $\mathrm{DF}_{2}$, which is connected with the closer irrigation interval of these two treatments. Statistically, there is no significant difference in ETP. As a result of lower drip fertigation frequency, the treatment $\mathrm{DF}_{3}$ showed 4.5 $\%$ to $5.5 \%$ higher average seasonal ETP, compared to $\mathrm{DF}_{2}$ and $\mathrm{DF} 1$, and the differences were statistically significant. Sezen et al. [16], reported lower evapotranspiration in drip irrigation treatment with moderate frequency from 6 to 10 days. Generally, the effect of drip fertigation on ETP is presented by the achieved results in treatments $\mathrm{DF}_{3}$ in comparison with $\emptyset_{\mathrm{B}} . \mathrm{DF}_{3}$ showed from $14.4 \%$ to $16.5 \%$ lower average monthly ETP and about $15 \%$ lower average seasonal ETP compared to $\emptyset_{\mathrm{B}}$. The results are statistically significant at 0.05 level of probability. Higher ETP in treatment $\emptyset_{\mathrm{B}}$ may be associated with continuous water stress and inadequate soil moisture and nutrient content, which also was reported in some other investigations $[9,17]$.

Table 3. Average (2005-2007) monthly and seasonal potential evapotranspiration (ETP in $\mathrm{m}^{3} / \mathrm{ha}$ ) of plastic-house grown pepper

\begin{tabular}{lcccccc}
\hline Treatments & May & June & July & August & September & Seasonally \\
\hline $\mathrm{DF}_{1}$ & $275.3^{\mathrm{a}}$ & $1043.8^{\mathrm{a}}$ & $1627.7^{\mathrm{a}}$ & $1512.7^{\mathrm{a}}$ & $428.5^{\mathrm{a}}$ & $4887.9^{\mathrm{a}}$ \\
$\mathrm{DF}_{2}$ & $271.7^{\mathrm{a}}$ & $1028.9^{\mathrm{a}}$ & $1618.7^{\mathrm{a}}$ & $1495.8^{\mathrm{a}}$ & $425.0^{\mathrm{a}}$ & $4840.1^{\mathrm{a}}$ \\
$\mathrm{DF}_{3}$ & $282.4^{\mathrm{a}}$ & $1088.5^{\mathrm{b}}$ & $1717.1^{\mathrm{b}}$ & $1580.3^{\mathrm{b}}$ & $438.9^{\mathrm{a}}$ & $5107.3^{\mathrm{b}}$ \\
$\emptyset_{\mathrm{B}}$ & $328.9^{\mathrm{b}}$ & $1245.1^{\mathrm{c}}$ & $1985.4^{\mathrm{c}}$ & $1816.9^{\mathrm{c}}$ & $505.1^{\mathrm{b}}$ & $5881.4^{\mathrm{c}}$ \\
\hline
\end{tabular}

${ }^{*}$ Values in rows followed by the same letter are not significantly different at the 0.05 probability level

Marketable pepper yield and fruit weight under different irrigation and fertilization regime

The influence of irrigation and fertigation regime on marketable pepper yield and fruit weight are shown in Table 4. From the data presented in Table 4, it can be concluded that the highest average pepper yield of $71.11 \mathrm{t} / \mathrm{ha}$ has been obtained in the treatment $\mathrm{DF}_{1}$, followed by $\mathrm{DF}_{2}$ with $68.40 \mathrm{t} / \mathrm{ha}$ or $2.71 \mathrm{t} / \mathrm{ha}$ less yield, and treatment $\mathrm{DF}_{3}$ with 8.5 and $5.79 \mathrm{t} /$ ha less yield when compared to $\mathrm{DF}_{1}$ and $\mathrm{DF}_{2}$. The lowest yield of $54.74 \mathrm{t} / \mathrm{ha}$ in our study was recorded in the control treatment $\left(\varnothing_{\mathrm{B}}\right)$. All three treat- ments with drip fertigation show statistically significant differences at 0.05 level of probability when compared to the control treatment $\varnothing_{\mathrm{B}}$. The lowest pepper yield in treatment $\varnothing_{B}$ in our study is a result of continuous soil moisture stress during mass fructification and inadequate soil nutrient procurement affected by the applied irrigation and fertigation technique, what was the purpose of other our research [17]. Candido et al. [13] emphasized that water deficit and reduced fertilizer availability, especially of nitrogen, are very harmful to bell pepper during the reproductive phase. Furthermore, the low pepper yield in treatment $\varnothing_{\mathrm{B}}$ in our study is associ- 
ated with the results of several researches where soil moisture stress and limited irrigation caused decreases to yield and vegetative growth of pepper [3, $12,18,28,44]$. For high pepper yields, an adequate water supply [31] and relatively moist soils are required during the total growing period [19, 27]. Therefore, the positive effect of drip fertigation on yield in our research is due to the continuous intake of the readily available water and nutrients in the small volume of soil, from where they were actively extracted by the plant. If nutrients are applied outside the wetted soil volume they are generally not available for crop use [45]. A number of other investigators emphasize results with higher pepper yields, where drip irrigation or drip fertigation was applied in comparison with conventional irrigation and fertilizerapplication $[9,13,15,16,29,30]$.

Table 4. Average (2005-2007) results for marketable pepper yield and fruit weight

\begin{tabular}{ccccc}
\hline Treatment & $\begin{array}{c}\text { Marketable } \\
\text { pepper yield (t/ha) }\end{array}$ & $\begin{array}{c}\text { Comparison with } \\
\text { treatment } \emptyset_{\mathrm{B}} \text { in \% }\end{array}$ & $\begin{array}{c}\text { Average pepper } \\
\text { fruit weight in } \mathrm{g}\end{array}$ & $\begin{array}{c}\text { Comparison with } \\
\text { treatment } \emptyset_{\mathrm{B}} \text { in \% }\end{array}$ \\
\hline DF1 & $71.11^{\mathrm{a}}$ & 129.9 & $73.15^{\mathrm{a}}$ & 128.4 \\
DF2 & $68.40^{\mathrm{a}}$ & 125.0 & $69.18^{\mathrm{b}}$ & 121.4 \\
DF3 & $62.61^{\mathrm{b}}$ & 114.4 & $63.42^{\mathrm{c}}$ & 111.3 \\
$\emptyset_{\mathrm{B}}$ & $54.74^{\mathrm{c}}$ & 100 & $56.99^{\mathrm{d}}$ & 100.0 \\
\hline
\end{tabular}

*Values in rows followed by the same letter are not significantly different at the 0.05 probability level

When we compared the drip fertigation treatments among themselves, it is clear that the high drip fertigation treatments $\mathrm{DF}_{1}$ and $\mathrm{DF}_{2}$ create a better environment for increasing of the yields in comparison with the low drip fertigation treatment $\mathrm{DF}_{3}$. Namely, treatment $\mathrm{DF}_{3}$ resulted in a $9.6 \%$ to $13.6 \%$ lower pepper yield in comparison to $\mathrm{DF}_{2}$ and $\mathrm{DF}_{1}$. According to Agele et al. [46], the trend to increase crop yields has led to frequent fertigation and therefore the time intervals between successive fertigation events have diminished to hours or even less. Bar Yosef [47] reported better pepper yields in treatment with drip fertigation 2 or 3 times a day $(71$ t/ha) compared to every day ( $68 \mathrm{t} / \mathrm{ha}$ ) or every 2 day drip fertigation (66 t/ha). Also, various researches reported better yields in pepper and other crops by using high-frequency in comparison with lowfrequency drip irrigation and fertigation [16, 48-52].

In the present study, we have documented that drip fertigation has an influence on the average pepper fruit weight too. The highest values of average pepper fruit weight were noted in treatments $\mathrm{DF}_{1}$ and $\mathrm{DF}_{2}$ with $73.15 \mathrm{~g}$ and $69.18 \mathrm{~g}$, then comes the treatment $\mathrm{DF}_{3}$ with $63.42 \mathrm{~g}$ and then comes the $\varnothing_{\mathrm{B}}$ with the lowest fruit weight $56.99 \mathrm{~g}$. All treatments under drip fertigation showed a statistically significant difference compared to the control treatment $\varnothing_{\mathrm{B}}$. Also, statistically significant differences were noted among any of the drip fertigation treatments. Generally, the lower average pepper fruit weight in treatment $\emptyset_{\mathrm{B}}$ compared to the drip fertigation treatments can be attributed to the irrigation and fertigation technique, while in $\mathrm{DF}_{3}$ as a result on prolongated drip fertigation frequency proceeded with a pretty higher quantity of water and nutrients in comparison with $\mathrm{DF}_{1}$ and $\mathrm{DF}_{2}$. The water deficit imposed during the late flowering-early fruit set phase causes lower size, number, and weight of pepper fruits as well as yield losses [13]. Abayomi et al. [14], reported that the number and weights of marketable fruits decreased by low soil moisture and increased by the application of nitrogen fertilizer. Also, our results from the present investigation correspond with those of Tanaskovik et al. [51], where drip irrigated and fertigated tomato was compared with banded and furrow irrigation. Furthermore, a number of other researchers report better yield components in pepper and different vegetable crops especially when different irrigation and fertigation techniques were applied [26, 30, 53].

Dry matter pepper yield and water use efficiency under different irrigation and fertilization regime

The results for total dry matter pepper yield show the same pattern as a fresh fruit yield, which would once again indicate yield increase with the simultaneous application of water and nutrients through the drip irrigation system. The results obtained for dry matter pepper yield (D. M. yield) in drip fertigation treatments showed a statistically significant difference at 0.5 level of probability compared with the control treatment $\varnothing_{\mathrm{B}}$. Similar results of D. M. yield in drip compared with furrow irrigated and drip fertigated compared with conventional irrigation and fertilization in pepper crop reported Antony and Singandhupe [9] and Tanaskovik et al. [17]. In this context, González-Dugo et al. [10] indicated that a continuous deficit of soil moisture affects the decrease of pepper D. M. yield. 
Table 5. Average (2005-2007) results for dry matter pepper yield and WUE

\begin{tabular}{ccccc}
\hline Treatment & $\begin{array}{c}\text { ETP } \\
\mathrm{m}^{3} / \mathrm{ha}\end{array}$ & $\begin{array}{c}\text { Dry matter pepper } \\
\text { yield }(\mathrm{t} / \mathrm{ha})\end{array}$ & WUE kg/m ${ }^{3}$ & $\begin{array}{c}\text { Comparison with } \\
\text { treatment } \emptyset_{\mathrm{B}} \text { in } \%\end{array}$ \\
\hline DF1 & $4887.9^{\mathrm{a}}$ & $12.24^{\mathrm{a}}$ & $2.50^{\mathrm{a}}$ & 162.3 \\
DF2 & $4840.1^{\mathrm{a}}$ & $11.98^{\mathrm{a}}$ & $2.47^{\mathrm{a}}$ & 160.4 \\
DF3 & $5107.3^{\mathrm{b}}$ & $10.19^{\mathrm{b}}$ & $1.99^{\mathrm{b}}$ & 129.2 \\
$\emptyset_{\mathrm{B}}$ & $5881.4^{\mathrm{c}}$ & $9.07^{\mathrm{c}}$ & $1.54^{\mathrm{c}}$ & 100.0 \\
\hline
\end{tabular}

*Values in rows followed by the same letter are not significantly different at the 0.05 probability level

Also, in the present study, the drip fertigation frequency points to differences in the yield of total dry matter, i.e. the treatment $\mathrm{DF}_{3}$ (average at seven days drip fertigation) has noted a yield lower by $2.05 \mathrm{t} / \mathrm{ha}$ in comparison to DF1, i.e. by $1.79 \mathrm{t} / \mathrm{ha}$ in comparison to DF2, and the differences were statistically significant at 0.05 level of probability. And many other authors $[17,50-52]$ have noted a higher dry matter yield individually by leaf, stem, fruit and totally in different vegetable crops in higher than in lower drip fertigation frequency.

The data obtained for water use efficiency (WUE) in our study are in relation to the previously mentioned results. From the data presented in Table 5 , it can be concluded that treatments $\mathrm{DF}_{1}$ and $\mathrm{DF}_{2}$ with 2.50 and $2.47 \mathrm{~kg} / \mathrm{m}^{3}$, respectively, have shown the highest water use efficiency. As a result of lower irrigation frequency, the treatment $\mathrm{DF}_{3}$ has shown $1.99 \mathrm{~kg} / \mathrm{m}^{3}$ WUE, or by 0.51 and $0.48 \mathrm{~kg} / \mathrm{m}^{3}$ lower produced dry matter yield compared to $\mathrm{DF}_{1}$ and $\mathrm{DF}_{2}$, and the differences were statistically significant. The differences between the drip fertigation treatments are a result of irrigation and fertigation frequencies. Sezen et al. [16] in their investigations with different irrigation regime in pepper crop, reported the highest yield and WUE in the treatment with drip irrigation frequency of 3 to 6 days, while in the drip irrigation treatment with irrigation frequency from 6 to 11 days and 9-15 days yield and water use efficiency decrease. Also, the results from our investigation correspond with those to Oğuzer $e t$ al. [25] were daily irrigated pepper show almost three times higher WUE in comparison with irrigation at every three days. Tanaskovik et al. [51] and Phene et al. [48], reported better WUE in high compared to low drip fertigated tomato crop. In this context, Bar-Tal et al. [54] indicated that high concentrations of nutrients used in prolongated fertigation lead to fluctuations from high or even excessive concentration immediately after irrigation in the rhizosphere to deficit levels as time proceeds. Therefore, high fertigation or irrigation frequency may represent a strategy to increase $\mathrm{N}$ uptake efficiency in many vegetable crops [55].

Furthermore, from the data obtained by WUE in our study, once again it is clear that the treat- ments under drip fertigation indicated the best results with a statistically significant difference in comparison with $\emptyset_{\mathrm{B}}$. If our results are presented in comparative values, then WUE in the treatments $\mathrm{DF}_{1}$ and $\mathrm{DF}_{2}$ were almost $60 \%$ higher in comparison with $\varnothing_{\mathrm{B}}$. Also, the treatment $\mathrm{DF}_{3}$ obtained more than $29 \%$ higher WUE in comparison with treatment $\emptyset_{\mathrm{B}}$. Our results correspond with several researches $[9,15,16,26]$, where different irrigation or fertigation techniques were evaluated over the pepper WUE. Also, a number of other researches with different vegetable crops reported higher WUE as a result of suitable drip irrigation and applying fertilizer's through the system in comparison with conventional irrigation and spreading of fertilizers on soil $[4,49,51,56]$. Moreover, higher WUE in drip fertigation treatments compared with $\emptyset_{B}$ in the present study can be associated with higher nitrogen fertilizer use efficiency (NFUE), which was the purpose of our other research [17]. Similar results as ours are observed in drip fertigation pepper, tomato, cucumber, melon and eggplant by Halitligil et al. [15]. Yasuor et al. [57], reported that a higher concentration of nitrogen in irrigation water significantly influenced its uptake in the whole plant and among the plant's organs. According to Drechsel et al. [58], improvements in nutrient use efficiency should not be viewed only as a result of fertilizer management, because nutrient plant use is closely related with soil water stress and water management.

Stagnari and Pisante [59] and Ouzounidou et al. [60] indicated that nitrogen is one of the major potential environmental contaminants and, therefore, our results for water use efficiency are very important for the environmental protection from nitrogen pollution, especially in intensive agriculture, where water and nutrients are the most utilized resources for obtaining greater yields per unit area.

\section{CONCLUSIONS}

From the results in the present study, it can be concluded that the irrigation and fertilization techniques and drip fertigation frequencies are significantly important in order to obtain higher marketable yield and pepper fruit weight, as well as dry 
pepper yield. Furthermore, water use efficiency was significantly increased with the application of fertilizer through drip irrigation as compared to the furrow irrigation and spreading of fertilizer on the soil. Moreover, high-frequency drip fertigation are highly recommended for improving water use efficiency. Therefore, for similar conditions of growing pepper as ours, to achieve appropriate marketable yield, we recommended drip fertigation with high frequency (two or four days) in order to increase water use efficiency and to minimize the environmental impact from nitrogen pollution.

\section{REFERENCES}

[1] A. Yazar, F. Gökçel, M. S. Sezen, Corn yield response to partial rootzone drying and deficit irrigation strategies applied with drip system, Plant Soil Environ., v. 55, n. 11 (2009), pp. 494-503.

[2] M. Moteva, V. Spalevic, A. Gigova, V. Tanaskovik, Water use efficiency and yielddependences for canola (Brassica napus, 1.) under irrigation, The Journal Agriculture \& Forestry, v. 62, n. 1, (2016), pp. 403-413. DOI: 10.17707/AgricultForest.62.1.42.

[3] A. Ferrara, S. Lovelli, T. Di Tommaso, M. Perniola, Flowering, growth and fruit setting in greenhouse bell pepper under water stress, Journal of Agronomy, v. 10, n. 1 (2011), pp. 12-19.

[4] Z. Ou Yang, X. Mei, Y. Li, J. Guo, Effect of Various Nitrogen Fertilizers and Their Levels on BigArch Shelter Cucumber Yield and Water Use Efficiency. Advance Journal of Food Science and Technology, v. 5, n. 6 (2013), pp. 726-731.

[5] K. Nagaz, M. Moncef Masmoudi, N. Ben Mechlia, Journal of Agriculture and Environment for International Development, v. 106, n. 2 (2012), pp. 85-103.

[6] F. Rubio, P. Flores, J.M. Navaro, V. Martinez, Effects of $\mathrm{Ca} 2+, \mathrm{K}+$ and cGMP on $\mathrm{Na}+$ uptake in pepper plants, Plant science, 165 (2003), pp. 1043-1049.

[7] K. Dorji, M. H. Behboundian, J.A. ZegbeDominguez, Water relations, growth, yield and fruit quality of hot pepper under deficit irrigation and partial rootzone drying, Scientia Horticulturae 104 (2005), pp. 137-149.

[8] V. Tanaskovik, The influence of irrigation regime with micro-irrigation on yield and water use efficiency of green pepper in Skopje region (in Macedonian), Ph.D. Thesis, Ss. Cyril and Methodius University, Faculty of Agricultural Sciences and Food, Skopje, (2009), p.152.

[9] E. Antony, R. B. Singandhupe, Impact of drip and surface irrigation on growth, yield and WUE of capsicum (Capsicum annum L.), Agricultural Water Management, 65 (2004), pp. 121-132.

[10] V. González-Dugo, F. Orgaz, E. Fereres, Response of pepper to deficit irrigation for paprika production, Scientia Horticulturae, 114 (2007), pp. 77-82.
[11] S. M. Sezen, A. Yazar, Y. Daşgan, S. Yucel, A. Akyıldı, S. Tekin, Y. Akhoundnejad, Evaluation of crop water stress index (CWSI) for red pepper with drip and furrow irrigation under varying irrigation regimes, Agriculture and water management, 143 (2014), pp.159-70.

[12] H. Kuşçu, A. Turhan, N. Özmen, P. Aydınol, O. A. Demir, Response of red pepper to deficit irrigation and nitrogen fertigation, Archives of Agronomy and Soil Science, v. 62, n. 10 (2016), pp. 1396-1410.

[13] V. Candido, V. Miccolis, A. R. Rivelli, Yield traits and water and nitrogen use efficiencies of bell pepper grown in plastic-greenhouse. Italian Journal of Agronomy, 3 (2009), pp. 91-100.

[14] Y. A. Abayomi, M. O. Aduloju, M. A. Egbewunmi, B.O. Suleiman, Effects of soil moisture contents and rates of NPK fertilizer application on growth and fruit yields of pepper (Capsicum spp.) genotypes, International Journal of AgriScience v. 2, n. 7 (2012), pp. 651-663.

[15] M. B. Halitligil, A. I. Akin, H. Kislal, A. Ozturk, A. Deviren Yield, nitrogen uptake and nitrogen use efficiency by tomato, pepper, cucumber, melon and eggplant as affected by nitrogen rates applied with dripirrigation under greenhouse conditions, In: Water balance and fertigation for crop improvement in West Asia, IAEA, Vienna, Austria, (2002), pp 99-110.

[16] S. M. Sezen, A. Yazar, E. Salim, Effect of drip irrigation regimes on yield and quality of field grown bell pepper. Agricultural Water Management, 81 (2006), pp. 115-131.

[17] V. Tanaskovik, O. Cukaliev, S. R. Kanwar, L. K. Heng, M. Markoski, V. Spalevic, Nitrogen Fertilizer Use Efficiency of Pepper as Affected by Irrigation and Fertilization Regime. Notulae Botanicae Horti Agrobotanici Cluj-Napoca, v. 44, n. 2 (2016), pp. 525-532.

[18] R. Wiertz, F. Lenz, The growth and yield of pepper (Capsicum annum L.) depending on water and nutrient supply, Gartenbauwissenschaft 52, (1987), pp. 39-45.

[19] B. Lazić, M. Djurovka, V. Marković, Ž. Ilin, Vegetable Production ( $2^{\text {nd }}$ ed) (in Serbian), Tampograf, Novi Sad, (2001).

[20] A. Alvino, M. Centritto, F. De Lorenzi, Photosynthesis report of sunlit and shade pepper (Capsicum annum) leaves at different positions in the canopy under two water regimes, Australia Journal of Plant Physiology, 21 (1994), pp. 377-391.

[21] S. Delfine, R. Tognetti, F. Loreto, A. Alvino, Physiological responses and growth responses to water stress in field-grown bell pepper (Capsicum annum L.), Journal of Horticulture Science and Biotechnology 77 (2002), pp. 697-704.

[22] P. W. Bosland, E. J. Votava, Peppers: Vegetable and Spice Capsicums, New Mexico State University, Las Cruces, USA, CABI Publishing, (2000).

[23] R. E. Jaimez, O. Vielma, F. Rada, C. GarciaNunez, Effects of water deficit on the dynamics of 
flowering and fruit production in Capsicum chinense Jacq in a tropical semiarid region of Venezuela, Journal of Agronomy and Crop Science, 185 (2000), pp. 113-119.

[24] J. Doorenbos, A. H. Kassam, Yield response to water, FAO Irrigation and Drainage Paper 33, Food and Agriculture Organization of the United Nations, Rome, (1986), pp. 157-160

[25] V. Oğuzer, A. Yazar, T. Yardimcioğlu, Effect of different cover materials and trickle irrigation intervals on the yield and quality of green peppers grown under high plastic tunnels, Turkish Journal of Agriculture and Forestry, v. 15, n. 2 (1991), pp. 406-422.

[26] O. Tekinel, R. Kanber, Trickle irrigation experiments in Turkey, In: Özay M., Biçak. A. H. (ed.): Modern and Traditional Irrigation Technologies in the Eastern Mediterranean, Ottawa, Canada, International Development Research Centre, (2002), pp. 27-72.

[27] G. C. Shao, N. Liu, Z. Y. Zhang, S. E. Yu, C. Chen, Growth, yield and water use efficiency response of greenhouse-grown hot pepper under Time-Space deficit irrigation, Scientia Horticulturae, v. 126, n. 2 (2010), pp. 172-179.

[28] A. Kurunc, A. Unlukara, B. Cemek ${ }_{2}$ Salinity and drought affect yield response of bell pepper, Acta agriculturae scandinavica section $b$-soil and plant science, v. 61, n. 6 (2011), pp. 514-522.

[29] V. Tanaskovik, O. Cukaliev, M. Moteva, M. Jankulovska, M. Markoski, V. Spalevic, R. Rusevski, Z. Bogevska., M. Davitkovska, The influence of irrigation and fertilization regime on some phenological stages and earliness of pruned pepper, The Journal Agriculture \& Forestry, v. 61, n. 2 (2015), pp. 7-17.

[30] S. M. Sezen, A. Yazar, H. Şengül, N. Baytorun, Y. Daşgan, A. Akyildiz, S. Tekin, D. Onder, E. Agcam, Y. Akhoundnejad, Ö. Gügercin, Comparison of drip- and furrow-irrigated red pepper yield, yield components, quality and net profit generation, Irrigation and Drainage 64 (2015), pp. 546-556

[31] H. Kirnak, Z. Gökalp, H. Demir, S. Kodal, E. Yildirim, Paprika pepper yield and quality as affected by different irrigation levels, Tarim Bilimleri Dergisi-Journal of Agricultural Sciences, 22 (2016), pp. 77-88.

[32] WRB, World reference base for soil resources 2014, FAO, Rome, (2015).

[33] J. Xie, E. S. Cardenas, W. T. Sammis, M. M. Wall, L. D. Lindsey, L.W. Murray, Effects of irrigation method on chili pepper yield and Phytophtora root rot incidence, Agricultural Water Management, 42 (1999), pp. 127-142.

[34] International Atomic Energy Agency, Use of isotope and radiation methods in soil and water management and crop nutrition, IAEA, Vienna, Austria, (2001).

[35] I. Rylski, M. Spigelman, Effect of different diurnal temperature combinations on fruit set of sweet pepper, Scientia Horticulturae, 17 (1982), pp. 101-106.
[36] M. Đurovka, B. Lazić, A. Bajkin, A. Potkonjak, V. Marković, Z. Ilin, V. Todorović, Vegetable and flower production in protected environment (in Serbian), University in Novi Sad, (2006).

[37] Y. H. Daşgan, K. Abak, Effects of plant density and number of shoots on yield and fruit characteristics of peppers grown in glasshouses, Turkish Journal of Agriculture and Forestry, v. 27, n. 1 (2003), pp. 29-35.

[38] Dj. Gvozdenović, A.Takac, Pepper (in Serbian) Agricultural library, Draganic, Beograd, (2004).

[39] C. Penella, S. G. Nebauer, S. López-Galarza, A. San Bautista, A. Rodriguez-Burruezo, A. Calatayud, Evaluation of some pepper genotypes as rootstocks in water stress conditions, Horticultural Science, v. 41, n. 4 (2014), pp. 192-200.

[40] Đ. Bošnjak, Irrigation of Agricultural Crops (in Serbian), University of Novi Sad, Faculty for Agriculture, Novi Sad, (1999).

[41] S. Dragović, Irrigation (in Serbian), The Research Institute for Field and Vegetable Crops, Novi Sad, (2000).

[42] S. Evett, Soil Water and Monitoring Technology, In: Lascano R. J. and Sojka, R. E. (ed): Irrigation of Agricultural Crops, Agronomy Monograph No.30, Second Edition, Madison, Wisconsin, USA, (2007).

[43] F. Orgaz, M. D. Fernández, S. Bonachela, M. Gallardo, E. Fereres, Evapotranspiration of horticultural crops in an unheated plastic greenhouse, Agricultural Water Management, 72 (2005), pp. 81-96.

[44] L. Dalla Costa, G. Gianquinto, Water stress and waterable depth influence yield, water use efficiency, and nitrogen recovery in bell pepper: lysimeter studies, Australian Journal of Agricultural Research, 53 (2002), pp. 201-210.

[45] R. J. Haynes, Principles of fertilizer use for trickle irrigated crops, Fertilizer research 6, Martinus Nijhoff/Dr W. Junk Publishers, Dordrecht, Netherlands, (1985), pp. 235-255.

[46] S. Agele, S. Shabtai Cohen, S. Assouline, Hydraulic characteristics and water relations of net housegrown bell pepper as affected by irrigation regimes in a Mediterranean climate, Environmental and Experimental Botany, 57 (2005), pp. 226-235.

[47] B. Bar-Yosef, Optimizing the use of drip fertigation: soil, water, nutrients and crop considerations, Training course notes: Irrigation and Fertigation in Controlled Environment, MASHAV, Israel, (2003).

[48] C. J. Phene, K. R. Davis, R. L. McCormick, R. B. Hutmatcher, J. D. Pierro, Water-fertility Management for Subsurface Drip Irrigated Tomatoes, Tomato and Pepper Production in the Tropics, International Symposium on Integrated Management Practices, Tainan, Taiwan, (1989), pp 323-338.

[49] I. Iljovski, O. Cukaliev, D. Mukaetov, V. Tanaskovik, Z. Jankuloski, Drip fertigation for improved crop production and environment protection (in Macedonian), In: Proceedings of the Ninth Symposium of Water Economy of the Republic of Macedonia, Ohrid, Macedonia, (2003), pp. 235-242. 
[50] O. Cukaliev, V. Tanaskovik, R. S. Kanwar, L. Heng Kheng, D. Mukaetov, Irrigation and fertigation effects on nitrogen use efficiency and tomato yield, International Agricultural Engineering Journal, 17 (2008), pp. 19-26.

[51] V. Tanaskovik, O. Cukaliev, D. Romić, G. Ondrasek, The influence of drip fertigation on water use efficiency in tomato crop production, Agriculture Conspectus Scientificus, v. 76, n. 1 (2011), pp. 57-63.

[52] B. Y. Çolak, A. Yazar, İ. Çolak, H. Akça, G. Duraktekin, Evaluation of crop water stress index (CWSI) for eggplant under varying irrigation regimes using surface and subsurface drip systems, Agriculture and Agricultural Science Procedia, $\mathbf{4}$ (2015), pp. 372-382.

[53] K. J. Petrevska, Cultivation of tomato on inert substrates in protected area (in Macedonian), $\mathrm{PhD}$ thesis, Faculty of Agriculture, Skopje, Macedonia, (1999).

[54] A. Bar-Tal, P. Fine, U. Yermiyahu, A. Ben-Gal, A, Hass, Practices that simultaneously optimize water and nutrient use efficiency, Israeli experiences in fertigation and irrigation with treated wastewater, In: Drechsel $P$ et al. (Eds), Managing water and fertilizer for sustainable agricultural intensification, IFA, IWMI, IPNI, IPI, Paris, (2015), pp 209-241.

[55] M. Farneselli, P. Benincasa, G. Tosti, E. Simonne, M. Guiducci, F. Tei, High fertigation frequency improves nitrogen uptake and crop performance in processing tomato grown with high nitrogen and water supply, Agricultural Water Management, 154 (2015), pp. 52-58

[56] I. Papadopoulos, Micro-irrigation systems and fertigation, In: Pereira L. S. et al. (Ed.). Sustainability of Irrigated Agriculture, Kluwer Academic Publishers, (1996), pp. 309-322.

[57] H. Yasuor, A. Ben-Gal, U. Yermiyahy, E. BeitYannai, S. Cohen, Nitrogen management of greenhouse pepper production, Agronomic, nutritional, and environmental implications. HortScience, v. 48, n. 10 (2013), pp. 1241-1249.

[58] P. Drechsel, P. Heffer, H. Magen, R. Mikkelsen, H. Singh, D. Wichelns, Managing water and nutrients to ensure global food security, while sustaining ecosystem services In: Drechsel P, et al. (Eds), Managing water and fertilizer for sustainable agricultural intensification, IFA, IWMI, IPNI, IPI, Paris, (2015), pp. 1-7.

[59] F. Stagnari, M. Pisante, Slow release and conventional $\mathrm{N}$ fertilizers for nutrition of bell pepper, Plant, Soil and Environment, v. 58, n. 6 (2012), pp. 268-274.

[60] G. Ouzounidou, C. Paschalidis, A. Petropoulos, A. Koriki, P. Zamanidis, A. Petridis, Interaction of soil moisture and excess of boron and nitrogen on lettuce growth and quality, Horticultural Science, v. 40, n. 3 (2013), pp. 119-125.

\title{
ЕФИКАСНО КОРИСТЕЊЕ НА ВОДАТА И ПРИНОС НА ПИПЕРКАТА ПРИ РАЗЛИЧНИ РЕЖИМИ НА НАВОДНУВАЊЕ И ЃУБРЕЊЕ
}

\author{
Вјекослав Танасковиќ ${ }^{1 *}$, Ордан Чукалиев ${ }^{1}$, Давор Ромич ${ }^{2}$, Габријел Ондрашек ${ }^{2}$, \\ Радован Савич ${ }^{3}$, Миле Маркоски ${ }^{1}$, Стојанче Нечковски ${ }^{1}$ \\ ${ }^{1}$ Факултет за земјоделски науки и храна, Универзитет „Св. Кирил и Методиј“, \\ Скопје, Република Македонија \\ ${ }^{2} 3$ емјоделски факултет, Универзитет во Загреб, Хрватска \\ ЗЗемјоделски факултет, Универзитет во Нови Сад, Србија
}

Главна цел на истражувањето беше да се утврди ефикасното користење на водата и приносот кај пиперката при различни режими на наводнување и ѓубрење. За оваа цел, извршивме тригодишни истражувања со пиперка одгледувана во пластеник во регионот на Скопско. Четири варијанти беа споредувани во истражувањето, од кои три со фертиригација $\left(\mathrm{DF}_{1}, \mathrm{DF}_{2}, \mathrm{DF}_{3}\right)$, додека четвртата варијанта беше наводнувана со бразди и класично ѓубрење (Ø $)$. Добиените резултати од истражувањето покажуваат дека варијантите со фертиригација (капково наводнување и ѓубрење преку системот) покажуваат статистички значајно поголем принос на пиперка во свежа состојба, како и на сувата материја од целото растение во споредба со варијантата

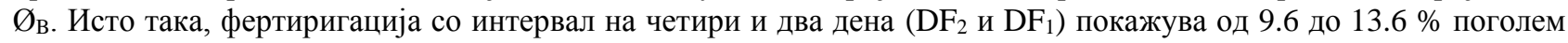
принос на свежа, односно од 17.6 до $20.1 \%$ на сува материја од целото растение споредено со варијантата со интервал утврден преку тензиометри $\left(\mathrm{DF}_{3}\right)$. Понатаму, нашите резултати укажуваат дека ѓубрењето преку систем капка по капка е многу ефективна алатка за обезбедување поефикасно користење на водата од растенијата. Имено, од добиените резултати може да се види дека за потрошен кубен метар вода варијантите $\mathrm{DF}_{1}, \mathrm{DF}_{2}, \mathrm{DF}_{3}$ и $\emptyset_{\mathrm{B}}$ создале $2.50,2.47,1.99$ и 1.54 принос на сува материја од целото растение.

Клучни зборови: наводнување со бразди; класично ѓубрење; фертиригација; принос; ефикасно користење на водата 